\title{
秋吉石灰岩層群における逆転構造の再検討
}

\author{
太田正道*鳥山隆 三** \\ 杉 村 昭 弘* 配川武彦*
}

\section{Restudy on the geologic structure of the Akiyoshi \\ Limestone Group, Southwest Japan}

\author{
Masamichi OTA, Ryuzo ToriYAMA, Akihiro SugIMURA, \\ and Takehiko HAIKAWA
}

\begin{abstract}
Based on the fact that the fusulinacean fossil zones are in reverse order at Kaerimizu doline and other localities in the Akiyoshi area, OzAWA (1923) discovered a large scale of recumbent folds in the Akiyoshi limestone Group. Since then the Akiyoshi area has been regarded as one of the most important places to study the geotectonic movement taken place at an interval between Late Paleozoic and Late Triassic, and to study fusulinacean foraminifers and their zonation. Accordingly numerous works have been appeared after Ozawa, such as SugIYAma (1939), Kobayashi (1941), HANZAWA (1944), TORIYAMA (1954, 1957, 1958), HASEGAWA (1958), YABE (1958), MuratA (1963), OTA (1968, 1971 ), etc. Some of them were lying stress on the geotectonic problems while others on the biostratigraphical ones.

So far as the micropaleontological and biostratigraphical studies of the Akiyoshi limestone Group are concerned, the results obtained by various authors are not so different from each other. However, it is remarkable that opinions are very much diverse on the geotectinic structure of the Akiyoshi limestone Group and the non-calcareous Paleozoic formations developed around the former, in spite of the fact that their geologic structures have important bearing on the consideration of the geotectonic history of Southwest Japan.

In order to make clear the true nature of geologic structures of the Akiyoshi limestone Group, detailed field survey has been carried out in the Kaerimizu area, northeastern part of the plateau, where the typical limestone sequence of reverse order is observed. As the results of our field studies (in scale of $1: 100$ to $1: 500$ ) we have confirmed ten fusulinacean zones in the Kaerimizu area among twenty fossil zones established by ToRIYAMA and OTA (1971) throughout whole Akiyoshi limestone Group.
\end{abstract}

* 秋吉台科学博物館

** 九州大学理学部地質学教室 


\begin{tabular}{|c|c|c|c|c|}
\hline \multirow{11}{*}{ 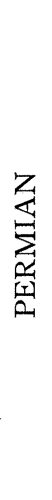 } & Upper & Lepidolina multiseptata shiraiwensis zone & $\mathrm{Pu}$ & $+25 \mathrm{~m}$ \\
\hline & & Colania douvillei zone* & $\operatorname{Pm} \delta$ & 40 \\
\hline & & Verbeekina verbeeki* & $\operatorname{Pm} \gamma$ & 20 \\
\hline & Middle & Neoschwagerina craticulifera zon $e^{*}$ & $\operatorname{Pm} \beta$ & 25 \\
\hline & & Afghanella schencki zone* & $\operatorname{Pm} \alpha_{2}$ & 15 \\
\hline & & Parafusulina kaerimizensis zone* & $\operatorname{Pm} \alpha_{1}$ & 25 \\
\hline & & Misellina claudiae zone* & $\mathrm{P} 1 \delta$ & 20 \\
\hline & & Pseudofusulina ambigua zone* & $\mathrm{Pl \gamma}$ & 40 \\
\hline & Lower & Pseudofusulina vulgaris zone* & $\mathrm{Pl} \beta$ & 50 \\
\hline & & Pseudoschwagerina (P.) muongthensis zone & $\mathrm{Pl} \alpha_{2}$ & 20 \\
\hline & & Triticites simplex zone* & $\mathrm{Pl} \alpha_{1}$ & +50 \\
\hline \multirow{9}{*}{ 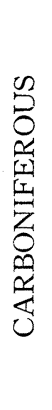 } & Upper & Triticites (s.l.) matsumotoi zone & $\mathrm{Cu}$ & +20 \\
\hline & & Beedeina akiyoshiensis zone & $\mathrm{Cm} \gamma$ & +30 \\
\hline & & Fusulinella biconica zone* & $\mathrm{Cm} \beta$ & -80 \\
\hline & Middle & Akiyoshiella ozawai zone & $\mathrm{Cm} \alpha_{3}$ & 20 \\
\hline & & Profusulinella beppensis zone & $\mathrm{Cm} \alpha_{2}$ & 20 \\
\hline & & Pseudostagffella antiqua zone & $\mathrm{Cm} \alpha_{1}$ & 20 \\
\hline & & Millerella yowarensis zone & $\mathrm{Cl} \gamma$ & 60 \\
\hline & Lower & Nagatophyllum satoi zone & $\mathrm{Cl} \beta$ & 70 \\
\hline & & Zaphrentoides sp. zone & $\mathrm{Cl} \alpha$ & 120 \\
\hline
\end{tabular}

Fossil zones in the Akiyoshi limestone Group. The zones with asterisk are found in the Kaerimizu area. (The $\mathrm{Pl} \alpha_{2}$ zone is included in the $\mathrm{Pl} \alpha_{1}$ zone in the Kaerimizu area.)

Among ten Permian fusulinacean zones found in the Kaerimizu area mentioned above, we have found that the Misellina claudiae zone is the best key bed, because $M$. claudiae (DEPRAT) has a characteristic features by which it is easily distinguishable from other soecies, and it concentrates in a limited horizon, though only $2 \mathrm{~m}$ in thickness. It is noted, moreover, that the limestone of Misellina claudiae zone consists mostly of micritic limestone, showing a considerable contrast in facies with the limestones of the zones above and below.

During the field studies were going on, the Akiyoshi-dai Science Museum conceived a project for subsurface biostratigraphy in the Kaerimizu area, because it is absolutely necessary to confirm the order of subsurface succession of fossil zones in the area. The Kaerimizu boring well No. 1 was thus settled about $200 \mathrm{~m}$ north of Kaerimizu doline where is $225.83 \mathrm{~m}$ above the sea-level ( $\mathrm{N}$. Long. $34^{\circ} 16^{\prime} 1^{\prime \prime}$; E. Lat. 131 $18^{\prime} 58^{\prime \prime}$ ). Because of poor budget for the project in the Science Museum, the drilling works have been carried out by ourselves, and No. 1 well reached at the depth of $250.56 \mathrm{~m}$ (about $25 \mathrm{~m}$ below the sea-level) in February, 1972.

Through detailed micropaleontological study on the materials obtained from the cores of No. 1 boring well, the following facts have been confirmed as shown in the columnar section (Fig. 3). 
In the depth from 0 to $162 \mathrm{~m}$ the Misellina claudiae, Parafusulina kaerimizensis, Afghanella schencki, Neoschwagerina craticulifera, Verbeekina verbeeki, and Colania douvillei zones are found successively without any stratigraphical break; namely, the fusulinacean zones in this part are completely reverse in order. At first, we expected to find the Lepidolina multiseptata shiraiwensis zone in some depth, which is the uppermost fossil zone in the Akiyoshi limestone Group and has not been found yet in the Akiyoshidai (s.s.), the northeastern half of the Akiyoshi limestone area. However, we have found that the Lepidolina multiseptata shiraiwensis zone does not exist, and the uppermost horizon in the No. 1 well is the Colania douvillei zone which is in contact with the Neoschwagerina craticulifera zone with a tectonic relationship.

From the depth of 162 to $242 \mathrm{~m}$, the Neoschwagerina craticulifera and Afghanella schencki zones are found; namely, this part of subsurface limestone is normal in order. The latter zone is again in tectonic contact with the Neoschrugerina craticulifera zone which is observed in the depth from 242 to $250.56 \mathrm{~m}$ in the lowest part of No. 1 boring well. It should be noted that the limestones of normal order below the depth of $162 \mathrm{~m}$ are more disturbed than those of reverse order above the depth of $162 \mathrm{~m}$, resulting in that many minor foldings and thrustings are found in the former.

From the facts described above, it is concluded without doubt that the Akiyoshi limestone Group is completely overturned in the subsurface of Kaerimizu area from 0 to $162 \mathrm{~m}$ in depth, and it is assumed that the foldings and thrustings were formed along the axial part of subsurface anticline whose axial plane is considered to be dipping to the north with small angles.

It is necessary to get further information on subsurface date not only from the Kaerimizu area but also from whole Akiyoshi limestone area to reach a decisive conclusion of geologic structure of the Akiyoshi limestone Group.

\section{Iはじめに}

秋吉石灰岩層群の分布地域は山口県の中央部よりやや西寄りの内陸部にあり, 美霖郡美東町, 同秋芳 町, 美羭市東部に広がる。この地域は NEE-SWW に約 $16 \mathrm{~km}$, NNW-SSE に約 $7.5 \mathrm{~km}$ のほぼ平行四 辺形に近い形の石灰岩台地である。中央部をほぼ南北流れる厚東川によつて東側の秋吉台（狭義）乙西 側の1)西の台にわけられている。前者の大部分 $45 \mathrm{~km}^{2}$ 注自然公園として国定公園に指定されており，その 万ちとくに重要な地域 $13.8 \mathrm{~km}^{2}$ 注地学的な人類の財産として特別天然記念物に指定されている。

1923 年小沢儀明がフズリナ化石の研究にもとづいて秋吉石灰岩層群を含む古生界の大規模な横卧褶曲構 造を発表して以来, 秋吉台は日本列島の地体構造発達史の重要な研究地として, また古生代古生物群の古 生物学的重要な研究地として内外の地質・古生物学者の注目をひいてきた。約半世紀にわたる絶え間ない 研究が続けられ, 数多くの重要な研究業績が発表されてきた。しかし, それにもかかわらず今日なお地質 構造の基本的解釈についてさえ未解決の問題が数多く残されている。このことはこの地域の研究がいかに 困難で根気のいる仕事であるかを物語つている。この小論では秋吉石灰岩層群のもつ地質構造, とくに地 層の広域逆転構造の存否について筆者等がこれまでに得た資料をもとに再検討を加え，秋吉石灰岩層群の 地質構造を論じた。

1) 西の台はさらに於福台, 岩永台, 江原台にわけられる。 


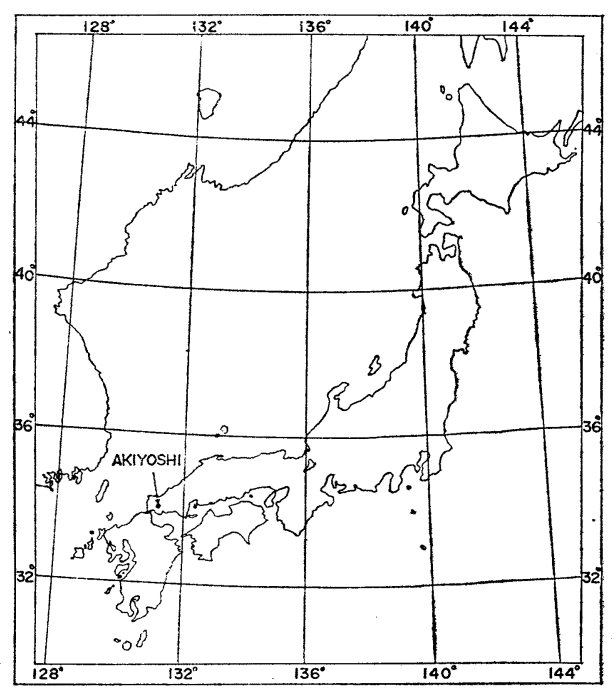

第 1 図 秋吉台の位置

(Fig. 1 Index map showing the location of Akiyoshi)

この研究を進めるにあたつては文化庁ならびに地元秋芳町の絶大な御援助，御協力をえたことを記し感 謝の意を表する。またこの研究の一部には文部省科学研究費を使用した。

\section{II 研究史のあらまし}

秋吉石灰岩層群とそれを取り巻く非石灰岩層群の研究は日本列島発達史の解明に極めて重要な役割を持 つており，これまでに数多くの研究が行われ，報告されてきた。これまでの研究の結果をみると，古生物 学的研究あるいは化石帯の分帯といつた分野では前進的業績が数多く報告されており, 各研究者によつて それほど大きな意見の相違は生じていない。しかし秋吉石灰岩層群とそれを取り巻く非石灰岩相の諸層群 との関係，あるいは秋吉石灰岩層群の持つ地質構造に関しては，同一地域の研究結果がよくもこれほど違 うものかと思われるほど各研究者の結論に著しい差異がみられる。一一真実はただ一つしかないのだが..

\section{…ㄴ.}

上記のように秋吉石灰岩層群のもつ地質構造の意義の重大さと, 各研究者の結論にあまりにも大きな距 たりのあることを考えると, 従来の地質構造についての主な研究の業績をたどつてみることは決してむだ なことではないように思われる。

化石層位学的研究を通して秋吉石灰岩層群の地質構造を論じた最初の研究は1923年小沢儀明によつて行 なわれた。この小沢の研究は本邦古生界の層位学的研究の基礎になつたばかりでなく, 成因論的構造地質 学の先駆として卓越したものである。小沢は秋吉石灰岩層群とその周囲に分布する非石灰古生層を詳しく 研究し, この地域の古生層の層序と化石帯を第 1 表のようにまとめた。小沢は秋吉台東部の“帰り水”や 於福台・江原附近などで化石帯が逆の順序であらわれること，すなわち 地形的に高い所に下位の化石帯 が，低い所に上位の化石帯が分布することから，秋吉石灰岩層群は全体として逆転構造を持つていると考 えた。江原および於福台周辺に Lepidolina multiseptata shiraiwensis (OzAWA) を含む粘板岩（第 1 表 のC）が石灰岩層の下位に分布するが，これは秋吉石灰岩層群よりも上位の地層で逆転したために最下位 に露出していると解釈した。小沢はこの大きな逆転構造の形成を秋吉石灰岩層群（第 1 表 B）と周辺の非 石灰古生層（第 1 表AとC）ともに南からの大きな圧力で南から北に横臥褶曲 (Liegende Falten) を形成 
し，その上翼が後の浸食で削り取られ，逆転した下翼だけが現在露出していると解釈した（第 2 図A）。 小沢はこの褶曲運動をペルム紀末と考光た。

1939 年に杉山敏郎は“㴆り水” の北にある“鹿の出”および美爾市通山附近では化石帯が逆転していな いことを明らかにし，また秋吉台の南に分布する砂岩・チャートからなる地層（第1表A）は，それから 発見された化石によつて秋吉石灰岩層群と同時異相の関係にあり, 従つて秋吉台地域の地層全体が逆転し ているといら小沢の結論には部分的に修正の必要があるといら見解を発表した。

1941年に小林貞一は「佐川造山輪䞡と日本列島の成因」において西南日本の層相解析にもとういて，小 沢とは全く対照的な地殼変動の動きと構造に対する見解を発表した。すなおち, 秋吉石灰岩層群（秋吉相） は現在位置に堆積したものではなく, 元来もつと北方（おそらく日本海のどこか）に堆積したものが非石 灭相の原地堆積性古生層（山口相）の上に大規模に北側から押し被せた Klippe であると解釈した（第 2 図B)。この地凯変動は三畳紀の美蕾層群堆積前に行なわれ，この造山運動後のモラッセ堆積物として美 爾層群が堆積したと説明した。このペルム紀末〜三畳紀後期前に起こつた造山運動を小沢の発見を記念し て「秋吉造山運動」と命名した。

1954 年, 1957 年, 1958 年鳥山隆三はフズリナ有孔虫群の詳細な微古生物学的研究を通して設定したフ ズリナ化石帯（第 2 表）の分布から秋吉石灰岩層群と周辺の非石灰相古生界の地質構造について 新しい知 見を明らかにした。

鳥山は非石灰相諸層群中に夾在するレンズ状石灰岩に産するフズリナの研究から，これらの諸層群は秋

第 1 表 小沢による層序と秋吉石灰岩の分帯

C レンズ状石灰岩を挾む頁岩, 角岩 $\mathrm{P}_{3}$ Sumatria annae subzone および砂岩の互層，厚さ $300 \sim 400$ $\mathrm{m}$

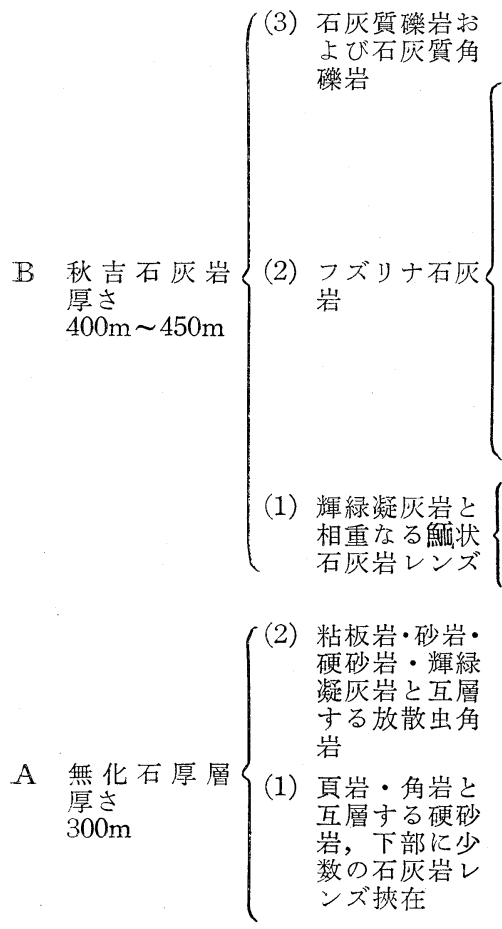

$\mathrm{P}_{2} \quad$ Fusulina(=Pseudofusulina) ambigua subzone

$\mathrm{CPg}$ Fusulina (=Parafusulina) lutugini subzone

$\mathrm{C}_{3} \quad$ Schwagerinaprinceps $(=P$ seu doschwagerina meranginensis) or Fusulina (=Pseudofusulina) vulgaris subzone Schwageina (=Pseudosc-

$\mathrm{C}_{3}{ }_{3}$ Schwagerina (=Pseudosch- hwageina) zone wagerina) moungthensis subzone

$\mathrm{C}_{2}$ Fusulinella bocki subzone Fusulinella zone

輝緑凝扊岩と
相重なる鮌状
石灰岩レンズ $\begin{cases}\mathrm{C}^{2}{ }_{1} & \begin{array}{l}\text { Lonsdaleia floriformis } \\ \text { subzone }\end{array} \\ \mathrm{C}^{1}{ }_{1} & \begin{array}{l}\text { Nagatophyllum satoi } \\ \text { subzone }\end{array}\end{cases}$
$\{$ Lonsdaleia zone subzone 
吉石灰岩層群と同時異相であり, 両者の堆積地域も接近していたと解䣋した。また秋吉石灰岩層群の逆転 部は北半部だけであり，南半部は正位な層序で，やや北に傾斜した原地性堆積の石灰岩層であると解釈し た（第 2 図 C)。すなわち逆転部の石灰岩層は北側の非石灰相古生層とともに南から北に向かつて横卧褶曲 を形成し, この準原地性逆転地塊がその後の運動によつて北方から南側に正位の原地性石灰岩層上に衝上 したと解䣋した。この 2 度の構造運動について, 第 1 回はペルム紀末から三盢紀初期にかけての秋吉造山 運動，第 2 回は三畳紀初期から中期にかけての大賀造山運動であるらと推定した。

1958 年, 1963 年長谷川美行はとくに“帰り水”附近の化石帯の分布を詳細に調查した結果, 化石帯の分 布が“帰り水” 凹地を中心としてほぼ円心円状に配列し，中心から離れるにしたがい下位のものが露出す ることから盈地状構造を考え, 秋吉石灰岩層群の広域逆転構造を否定した。さらに秋吉石灰岩層群全体の 構造に関しても全く逆転部はなく石灰岩層法ゆるやかに褶曲しているのみであるとし，秋吉造山運動の存 在にも疑問があると述べた（第 2 図 $\mathrm{E}$ )。

1958 年, 矢部長克はそれまでの多くの研究者による地質構造の解釈の相違点，ならびに造構造運動の時 代についての解釈の問題点を指摘した。

1961 年村田正文は秋吉石灰岩層群おうび周辺の非石灰相古生層に関する再研究の結果を発表した。村田 によれば非石灰相古生層と秋吉石灰岩層群とは互いに漸移し，同一構造を示す原地性堆積物であるとし た。またその構造洼南側からの圧力による小褶曲の繰り返しで，南側のものが北側にそれぞれ衝上した同 斜褟曲と多くの南からの衝上断層の組み合わせによつて形成されたものと解釈した。その結果大きな逆転 地層の存在を否定し，“帰り水”地域では長谷川の見解を支持した。この褶曲運動は美孀層群堆積前，すな わち,ペルム紀後三畳紀の Ladinic 前であり, 衝上運動は褶曲運動に伴なうもののほか, 美爾層群堆積 後にもひきつづき起こったであろうと結論した。

1967 年太田正道は “州り水” 附近の地質精查 $1 / 1000$ を行ない，化石帯の分布，配列の順位に加えて石灰 岩層の走向・傾斜の測定，ならびに鍵層の追跡から再び“帰り水”地域における秋吉石灰岩層群の広域逆 転を証明した（第 4 図，1967 年太田より筆者らにより修正改作）。1968 年太田は 秋吉石灰岩層群の化石 相・岩相の解析による古環境の復原を試み，秋吉石灰岩層群が地向斜型生物礁複合体として原地堆積し， 一地質時代には環礁として発達していたことを明らかにした。この生物礁複合体は石炭紀前期からぺルム 紀後期まで発達したのち, 古生代末から三畳紀初期にかけて北からの圧力による 褶曲運動により北半部が 大きく横臥褶曲し，南半部の原地性の秋吉石灰岩層群上に堆し被せたと結論した。

1971 年筆者らは秋吉石灰岩層群の逆転構造の最初の発見地であり, 最も典型的に逆転層が観察される地 域である“㴆り水”地域でボーリングの岩芯採集による地下生層序学的調查を進め,“帰り水”地域の逆 転層の存在を立証しその一部を発表した。また太田，鳥山は総ての既知の資料を整理し，化石帯の分布に もとづく秋吉石灰岩層群全域の地質図を発表した。これを一部分修正したものが第 5 図地質図である。

第 2 表 鳥山による秋吉石灰岩磷群の分帯

Yabeina (=Lepidolina) Zone: Yabeina (=Lepidolina multiseptata) shiraiwensis Zone Pu $\alpha$

Neoschwagerina Zone

: Neoschwagerina (=Colania) douvillei subzone $\operatorname{Pm} \delta$

Verbeekina verbeeki subzone $\mathrm{Pm} \gamma$

Neoschwagerina craticulifera subzone $\operatorname{Pm} \beta$

Parafusulina Zone

: Parafusulina kaerimizensis subzone $\operatorname{Pm} \alpha$

Pseudofusulina ambigua subzone $\mathrm{Pl} \gamma$

Pseudoschwagerina Zone

: Pseudofusulina vulgaris subzone $\mathrm{Pl} \beta$

Triticites simplex subzone $\mathrm{Pl} \alpha$

Fusulinella Zone

Fusulinella biconica Zone $\mathrm{Cm} \beta$

Profusulinella Zone

Profusulinella beppensis Zone $\mathrm{Cm} \alpha$

Millerella Zone

Millerella sp. $\alpha$ Zone $\mathrm{Cl}$ 
第 2 図 諸研究者の解釈による秋吉石灰岩 台地の断面図

(Fig. 2 Geological pratiles of the Akiyoshi limestone plateau by the previous and the present authors.)

A. 小沢儀明の解䣋 : 秋吉石灰岩は周囲の 非石灰相の古生層とともに横臥褶曲乙 ている。ch：チャート, sh: 頁岩, clsl : スレート, ss : 砂岩, $\mathrm{C}_{1-3}$ : 石炭 系の下, 中, 上部, $\mathrm{P}_{1-3}$ : 二畳系下, 中, 上部。

B. 小林貞一の解釈 : 秋吉石灰岩は原地性 堆積物の非石灰相の諸層群上に北側か ら移動してきたクリッペである。 $\mathrm{Cm}$, $\mathrm{Cu}$ : 石炭系中部, 上部, $\mathrm{P}_{1}, \mathrm{Pm}:$ 二 胃系下部, 中部, $1 \mathrm{H}, \mathrm{vH}$ : 下部, 上 部角岩層。

C. 鳥山隆三の解䣋 : 秋吉石灰岩の北半部 南から北への横臥褶曲の下翼, 南半部 は原地性堆積物で正位, 横臥褶曲の後 北から南に衝上している。Tsu：常森 層群, $\mathrm{O}_{1-2}$ : 大田層群, : $\mathrm{B}_{1-4}$ : 別府層 群, $\mathrm{Cm}$ : 石炭系中部, $\mathrm{P}_{1}, \mathrm{Pm}, \mathrm{Pu}$ : 二畳系下部, 中部, 上部。

D. 村田正文の解䣋 : 傾斜褶曲と, 南から 北への衝上である。秋吉石灰岩も非石 灰質古生層群む略同じ構造である。ま た古生層は後に美弥層群上に衝上して いる。 $\mathrm{K}$ : 関門層群, $\mathrm{B}_{1-3}$ : 別府層群, $\mathrm{T}$ : 於福層群堤層, $\mathrm{O}_{1-2}$ : 大田層群, $\mathrm{C}_{1} \cdots \mathrm{P}_{\mathrm{IV}}$ : 化石帯の連続を示す, $\mathrm{M}$ : 美弥層群。

E. 長谷川美行の解瀵 : 逆転していなくて 裮曲のくりかえしである。4: 赤色凝 灰質頁岩，5: 緑色一紫色玄武岩質凝 灭岩, 6-16: 秋吉石灰岩層群 (石灰系 二畳系), 17-18: 非石灰質古生層, 17 : チャート, 18 : 砂岩, 19 : 関阴層群。

$\mathrm{F}$ : 太田正道・鳥山隆三の解釈 : 秋吉石灰 岩の北半部は北から南一横卧褚曲し, 向斜軸部に出来た衝上断層でその下翼 部が南半部の原地性堆積物で正位の部 分に衝上している。 $\mathrm{Cl} \cdots \mathrm{Cm}$ : 石炭系 下部, 中部, $\mathrm{Pl} \cdots \mathrm{Pu}$ : ペルム系下部,
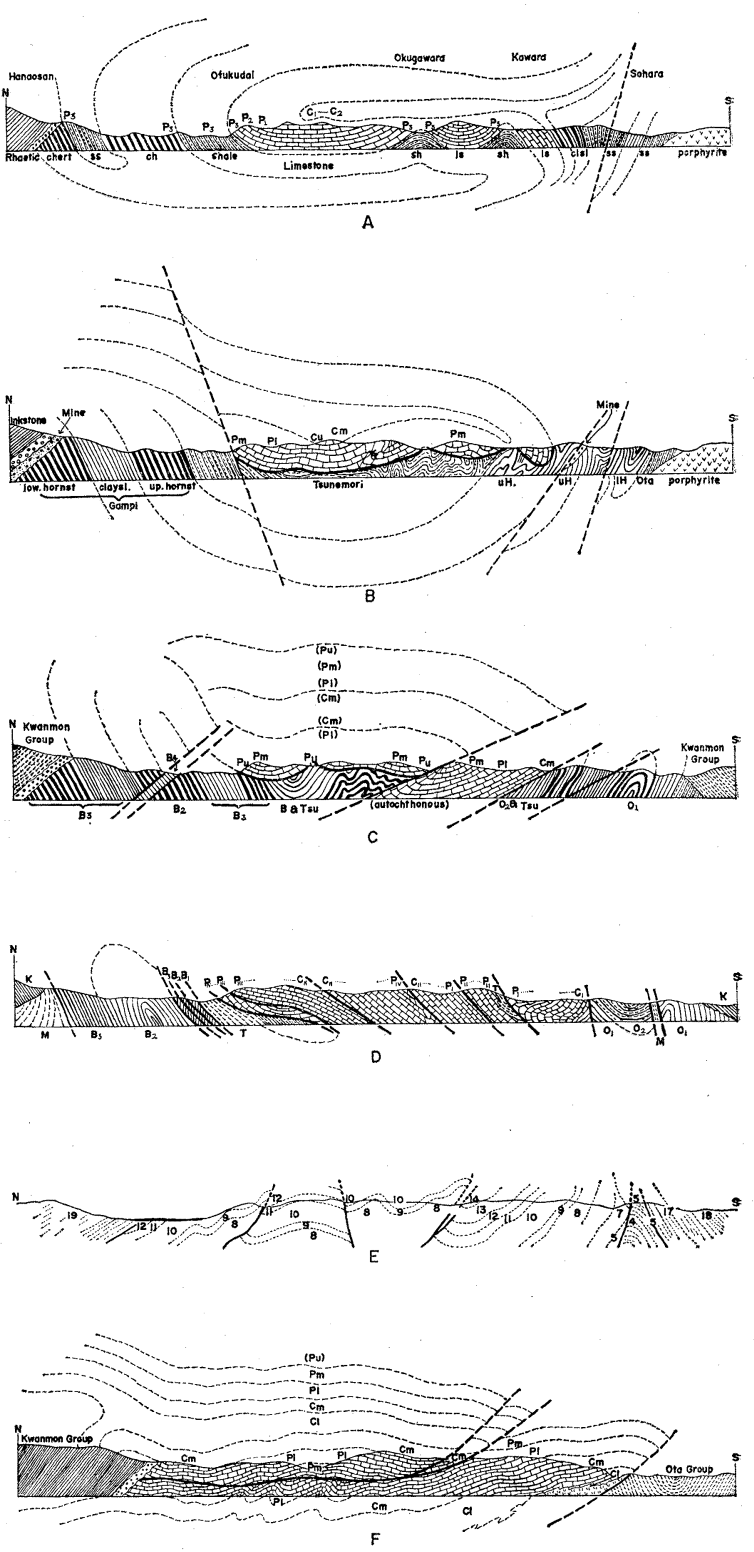
中部, 上部。

1971 年森永・太田は西の台真木地域において秋吉石灰岩層群の石灰石採石に関する鉱量調査のために掘 られた深度 100 m 235.5 m のボーリング 15 本の岩芯より約 1000 枚の薄片を作製するとともに地表調査 を加え褶曲逆転の形態を明らかにした。1971 年柳田, 太田, 杉村, 配川は秋吉台東部猪出台地域の逆転構 造と地質を明らかにした。

以上がこれまで発表された秋吉石灰岩層群と, その周辺の非石灰相古生層の地質構造と造構造運動に関 
する主なものであるが，なお末解決な多くの問題があり，その解明には精度の高い研究が必要である。

\section{III 秋吉石灰岩層群の逆転構造の再検討}

筆者らは前述のように秋吉石灰岩層群における地質構造と造構造運動に長年興味をもつてきた。また， その地質学的特別天然記念物としての意義の大きさを認め. 研究者による解釈の相違の原因を究明するた め，できるだけ多くの資料の集積を行なってきた。その一環として秋吉石灰岩層群中に含まれる化石群， とくにサンゴ, フズリナ類の系統発生的研究を基礎に精細な生層序学的研究を進め, できるだけ化石帯を 細分してその分布を追跡した。この研究を進める一方, 秋吉石灰岩層群における逆転層の再検討を行なう ため逆転層が典型的に分布するとされているっ帰り水”地域におけるボーリングの岩芯に含まれるフズリ ナによつて地下層序学的研究を進めてきた（前述のように1958年以来“帰り水”地域における逆転層の存 在に疑問が起こつたためである)。筆者らが筆者ら自身で海抜 $225.8 \mathrm{~m}$ 地点より実施した“帰り水”学術 第 1 号ボーリングは深度 $250 \mathrm{~m}$ で完了し，現在第 2 号ボーリングにとりかかりつつある。第 1 号ボーリン グの岩芯から得られたフズリナ類の生層序学的検討結果（第 4 図）にもとづき，筆者らは“帰り”水地域 ならびに秋吉石灰岩層群全域の地質図・地質断面図を作成した（第 3 図，第 5 図)。

\section{1. 秋吉石灰岩層群の生層序}

第 3 表 秋吉石灰岩層群の生層序と化石帯

\begin{tabular}{|c|c|c|c|c|}
\hline \multicolumn{2}{|c|}{ Geological age } & Name of fossil Zone & Sign & $\begin{array}{l}\text { Averaging } \\
\text { thickness }\end{array}$ \\
\hline \multirow{3}{*}{ Permian } & Upper & Lepidolina multiseptata shiraiwensis Zone & $\mathrm{Pu} \alpha$ & $+25 \mathrm{~m}$ \\
\hline & Middle & $\begin{array}{l}\text { Colania douvillei Zone } \\
\text { Verbeekina verbeeki Zone } \\
\text { Neoschwagerina craticulifera Zone } \\
\text { Afghanella schencki Zone } \\
\text { Parafusulina kaerimizensis Zone }\end{array}$ & $\begin{array}{l}\operatorname{Pm} \delta \\
\operatorname{Pm} \gamma \\
\operatorname{Pm} \beta \\
\operatorname{Pm} \alpha_{2} \\
\operatorname{Pm} \alpha_{1}\end{array}$ & $\begin{array}{l}40 \mathrm{~m} \\
20 \mathrm{~m} \\
25 \mathrm{~m} \\
15 \mathrm{~m} \\
25 \mathrm{~m}\end{array}$ \\
\hline & Lower & $\begin{array}{l}\text { Misellina claudiae Zone } \\
\text { Pseudofusulina ambigua Zone } \\
\text { Pseudofusulina vulgaris Zone } \\
\text { Pseudoschwagerina (P.) muongthensis Zone } \\
\text { Triticites simplex Zone }\end{array}$ & $\begin{array}{l}\mathrm{Pl} \delta \\
\mathrm{Pl} \gamma \\
\mathrm{Pl} \beta \\
\mathrm{Pl} \alpha_{2} \\
\mathrm{Pl} \alpha_{1}\end{array}$ & $\begin{array}{r}20 \mathrm{~m} \\
40 \mathrm{~m} \\
50 \mathrm{~m} \\
20 \mathrm{~m} \\
\pm 50 \mathrm{~m}\end{array}$ \\
\hline \multirow{3}{*}{ Carboniferous } & Upper & Triticites (S. I) matsumotoi Zone & $\mathrm{Cu} \alpha$ & $\pm 20 \mathrm{~m}$ \\
\hline & Middle & $\begin{array}{l}\text { Beedeina akiyoshiensis Zone } \\
\text { Fusulinella biconica Zone } \\
\text { Akiyoshiella ozawai Zone } \\
\text { Profusulinella beppensis Zone } \\
\text { Pseudostaffella antiqua Zone }\end{array}$ & $\begin{array}{l}\operatorname{Cm} \gamma \\
\operatorname{Cm} \beta \\
\operatorname{Cm} \alpha_{3} \\
\operatorname{Cm} \alpha_{2} \\
\operatorname{Cm} \alpha_{1}\end{array}$ & $\begin{array}{r} \pm 30 \mathrm{~m} \\
-80 \mathrm{~m} \\
20 \mathrm{~m} \\
20 \mathrm{~m} \\
20 \mathrm{~m}\end{array}$ \\
\hline & Lower & $\begin{array}{l}\text { Millerlla yowarensis Zone } \\
\text { Nagatophyllum satoi Zone } \\
\text { Zaphrentoides sp. Zone }\end{array}$ & $\begin{array}{l}\mathrm{Cl} \gamma \\
\mathrm{Cl} \beta \\
\mathrm{Cl} \alpha\end{array}$ & $\begin{array}{r}60 \mathrm{~m} \\
70 \mathrm{~m} \\
120 \mathrm{~m}\end{array}$ \\
\hline & & & & $\pm 770 \mathrm{~m}$ \\
\hline
\end{tabular}


これまでの研究の結果明らかになつた秋吉石灰岩層群の生層序と化石带, ならびに層厚は第 3 表のとおり ぐある。

秋吉石灰岩層群の化石带の概略を層序の下位より述べる。

\section{1) Zaphrentoides sp. 帯 $\mathrm{Cla}$}

秋吉石灰岩層群の最下部には“シャールスタイン”と呼ばれる塩基性海底火山噴出物よりなる $100 \mathrm{~m}$ 前後の層と，これに交指する oolitic な岩相を主体するフズリナ類を全く含まない石灰岩層がある。こ の“シャールスタイン”と石灭岩層中に単体サンゴ, 腕足類, こけ虫類, 小型有孔虫などを産する。これ らのらち Zaphrentoides sp. で代表される下部をZaphrentoides 带 $\mathrm{Cl} \alpha$ とした。主な産出化石は次のと おりである。

Zaphrentoides sp., Syringothyris spp., Delepinea sayamensis, D. sinuata.

本宜はョーロッパの Viséan 下部，北米の Meramecian に対比される。

最近これまでこの化石帯に属していると考えていた石灰岩の下部より腕足類 Marginatia toriyamai YANAGIDA (M・S) 化石群が柳田・太田によつて発見され, Zaphrentoides 帯の下位に Upper Tournaisian に属する石灰岩層の存在が明らかになつた。しかし，現在までこの化石帯に属する石灰岩層がどのよ うな分布域をもつているのか未確認なことと, 化石の記載が未完了であるため本帯に含め分帯しなかつた。

\section{2) Nagatophyllum satoi 帯 $\mathrm{Cl} \beta$}

本帯は Zaphrentoides sp. 帯の上部に整合に累重するもので $\mathrm{Cl} \alpha$ 帯と同様，全くフズリナ類を含まな い。層厚は $70 \mathrm{~m}$, 分布域は秋吉台の南縁部より東部に加けて広く分布する。本帯中よりはサンゴ，腕足 類, こけ虫，小型有孔虫を多産する。主要産出化石は次のとおりである。

Nagatophyllum satoi, Clisiophyllum awa atetsuense, Cyathaxonia n. sp., Lonsdaleoides toriyamai, Gigantoproductus spp., Stenopora akagoensis, Sulcoretepora cf. S. complicata, Hayasakapora otai, Endothyra spp., Mediocris sp.

本帯はヨーロッパの Viséan 中部, 北米の Chestarian 下部に対比される。

\section{3) Millerella yowarensis 帯 $\mathrm{Cl} \gamma$}

本带は Nagatophyllum satoi 带上に整合に重なる。岩相は礁相・礁湖相ともに発達し，下部 2 帯に比 心゙て分布も著しく広くなつている。層厚は平均 $60 \mathrm{~m}$ である。主な産出化石は次のとおりである。

Millerella yowarensis, M. toriyamai, Eostaffella etoi, Stylidophyllum ozawai, Clisiophyllum awa, Lonsdaleoides sp., Cleiothyridina expansa, C. royssi, Phricodothyuris insolita, Straparollus (S.) otai, Turhonitella yanagidai, T. ryugohoensis, Pseudohatostomella cf. P. granulosa, Stenopora pusilimonila, Streblotrypella astrovae, Penniretepora ofukuensis, Leioclema uzuraensis,

本帯はヨーロッパの Viséan 上部, 北米の Chesterian 中部に対比される。

\section{4) Psudostaffella antiqua 帯 $\mathrm{Cm} \alpha_{1}$}

本帯は Millerella yowarensis 帯の上に累重する。Millerella yowarensis 帯との関係はこの化石帯の 分布からみると不整合関係ではないかと考察されるが，地表における露頭観察では明らかでない。秋吉台 北東部の赤郷・猪出台附近で模式的に観察される。層厚は約 $20 \mathrm{~m}$, 産出化石の主なものは次のとおりであ る。

Pseudostaffella antiqua, Millerella yowarensis, M. sp. Eostaffella sp.

本帯はヨーロッパの Namurian, ソ連の Boshikirian, 北米の Springeran, Morrowan に対比される。

\section{5) Profusulinella beppensis 帯 $\mathrm{Cm} \mathrm{a}_{2}$}

本带は Pseudostaffella antiqua 帯上に整合に重なり，極めて薄い層にもかかわらず，分布域は秋吉石 灭岩層群分布域全体におよんでおり，鍵層として有効である。層厚は平均 $20 \mathrm{~m}$, 主要産出化石は次のとお 
りである。

Profusulinella beppensis, P. rhomboides, P. daiyamensis, Agathiceras toriyamai, Bisatoceras akiyoshiense, Eoasianites sp. aff., E. suborientaris, Diaboloceras ? sp., Taisyakuphyllum sp. 本帯はソ連の Moscovian 最下部に，北米の Derryan 下部に対比される。

6) Akiyoshiella ozawai 帯 $\mathrm{Cma}$

本帯は Profusulinella beppensis 带に整合に累重し，Akiyoshiella ozarvai を代表種として分帯した ものである。主要産出化石は次のとおりである。

Akiyoshiella ozawai, Stoffella akagoensis, Millerella sp.

層厚は約 $20 \mathrm{~m}$ で秋吉台東北部猪出台地域で典型的に 観察される。本帯はソ連の Moscovian 下部, 北米 の Derryan の中部に対比される。

\section{7) Fusulinella biconica 帯 $\operatorname{Cm} \beta$}

秋吉石灰岩層群の石炭系化石帯中では Millerella yowarensis 帯とともに広く全域に分布し中部石炭系 上部の代表的化石帯となつている。本帯の層厚は約 $80 \mathrm{~m}$ で Fusulinella 属によつて特徴づけられてい る。本帯下部は Fusulinella 属としては原始的で 小型の F. simplicata で特徵つけられ, 中部は, F. biconica, 上部は $F$. itoi で特徴づけられる。主要産出化石は次のとおりである。

Fusulinella biconica, F. cf. bocki, F. simplicata, F. subspherica, F. itoi, Pseudopavona sp. 本化石帯の分布は前述のとおり極めて広く, よく発達しているが，とくに秋吉台南部，博物館附近，鹿の 出から鐙峠にかけて典型的に 発達している。本帯はヨーロッパ・ソ連の Moscoviam の主要部, 北米の Derryan 上部に対比される。

\section{8) Beedeina akiyoshiensis 帯 $\mathrm{Cm} \gamma$}

本帯は Fusulinella biconica 帯の上に累重し, Beedeina akiyoshiensis で代表される。中部石炭系最 上部を示す化石帯として重要である。石灰岩の岩相は下位の Fusulinella biconica 帯のそれとはやや異 なつて拈り, 堆積環境にやや変化が起こつたものと考えられる。この化石帯は猪出台, 秋吉台南縁部の経 塚の北側に典型的にみられる。層厚は平均 $30 \mathrm{~m}$ で主要産出化石は次のとおりである。

Beedeina akiyoshiensis, B. sp., Fusulinella itoi, Fusulinella sp., Wedekindellina sp., Nankinella

sp. この他かなりのサンゴ類が発見されている。

本帯はヨーロッパ，ソ連の Moscovian 上部，北米の Desmoinesian に対比される。

\section{9) Triticites (S. I.) matsumotoi 帯 $\mathrm{Cu} a$}

本帯は上部石炭系に属する化石帯で, 従来秋吉石灰岩層群では欠けていると考えられていた化石帯であ る。現在までのところ, 本帯の分布はごく限られ, 有料道路料金所の北側約 $200 \mathrm{~m}$ に知られているにすぎ

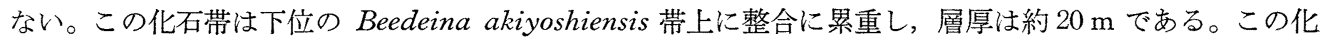
石帯の主要産出化石は次のとおりである。

Triticites (S. l.) matsumotoi, T. cf. yayamadakensis, Quasifusulinr longissima, Fusulinella sp. Ozarvainella sp.

分布域が極めて部分的であるのは上に重なるペルム系の石灰岩層との関係が 傾斜不整合であるためとも考 えられるが，正確な両者の層序的関係は今後の研究にまたなければならない。本帯はソ連の Kassimovskian, 北米の Kawvian 下部に対比される。

\section{0) Triticites simplex 帯 Pla}

本帯はペルム系最下部の 化石帯で Triticites (S. 1.) matsumotoi 帯, Beedeina akiyoshiensis 帯, Fusulinella biconica 帯に接し，それらとは不整合関係に累重する。これまでは平行不整合であろらと考 えられていたが傾斜不整合で重なる可能性が強い。層厚は平均 $50 \mathrm{~m}$ で分布域は極めて広く, 秋吉石灰岩 層のほぼ全分布域に広がつている。とくに秋吉台南部・秋吉台科学博物館北部において典型的に観察され 
る。本帯は豊富な Triticites 属で特徴づけられており，主要化石は次のとおりである。

Triticites simplex, T. ozawai, T. montipara, T. biconica, T. suzukii, T. noinskyi paula, T. arctica, Quasifusulina longissima, Schubertella kingi.

本帯はテチス地域の Asselian 下部, 北米の Wolfcompian 下部に対比される。

\section{1) Pseudoschwagerina (P.) muongthensis 帯 Pla}

本帯は Triticites simplex 帯の上に整合に重なるもので, これまでTriticites simplex 帯とされてい た石灰岩層の上部を分帯したものである。この化石帯は Pseudoschwagerina (P.) muongthensis が急激 に優勢になる化石群によつて特徴づけられ，層厚注平均 $20 \mathrm{~m}$ である。本帯は秋吉台南部にとくに典型的 に発達している。主要化石は次のとおりである。

Pseudoschwagerina (P.) muongthensis, Triticites simplex, T. haydeni, T. noinskyi paula,

T. tantula, T. arctica, Dunbarinella? sp., Schwagerina regularis

本帯はテチス地域の Asselian 中部, 北米の Wolfcampian 中部に対比される。

12) Pseudofusulina vulgaris 帯 $\mathrm{PI} \beta$

本帯は Pseudoschwagerina (P.) muongthensis 帯に整合に累重するもので分布が広い。この化石帯に は Schwageriniae 亜科に属する属が出そろい，秋吉石灰岩層群の化石群の中で，この化石帯はフズリナ の産出種数が最も多く50 種以上に達する。層厚は約 $50 \mathrm{~m}$ で秋吉台では真名岳, 地獄台, 西山東斜面, 妙 見原附近にかけて最もよく観察される。主な産出化石の属は次のとおりである。

Pseudofusulina, Triticits, Paraschwagerina, Pseudoschwagerina, Schwagerina, Dunbarinella 本化石帯はテチス地域の Asselian 上部, 北米の Wolfcampian 上部に対比される。

13) Pseudofusulina ambigua 帯, $\mathrm{Pl} \gamma$

本帯の設定については各研究者により意見が異なる。村田（1961）は本帯の構成種は下位のPseudofusulina vulgaris 帯の要素であるという疑問から本帯を区分せず Parafusulina kaerimizensis 帯に含 めている。長谷川 (1963) は本帯の代りに Pseudofusulina kraffti magna 帯を設定し, Misellina $c^{c}$ laudiae 帯もこれに含めている. 太田はこの化石帯に属する化石群集を古生態的に検討した結果, Pseudofusulina kroffti magna は礁湖相を, Pseudofusulina ambigua は礁平坦部砂相を代表する種であ り，互いに住み分け現象を示し，共存することは少ないことを明らかにした。しかし，P．ambigua は死 後流されて礁湖相の堆積物に混じる可能性が多いため量的には少ないが P. kraffti magna と伴なつて産 出することがわかつてきた。したがって広域な対比のためには P. ambigua を代表種とした方が適当で あると考えている。本帯に属する石灰岩層は厚さは $40 \mathrm{~m}$ で, “帰り水”一帯, 秋吉台南部, 西の台 409.5 $\mathrm{m}$ 高地一带に典型的に分布している。本帯の主要産出化石は次のとおりである。

Pseudofusulina ambigua, P. kraffti magna, P. vulgaris, P. yowarensis, P. globosa, P. megaspherica, P. (?) kyowaensis, T. haydeni, T. biconica, Schwagerina regularis, S. krotowi, Nankinella nagatoensis, Schubertella kingi,

本帯はテチス地域の Sakmarian（S. S.) 下部，北米の Leonardiam の最下部に対比される。

\section{4) Misellina claudiae 帯 $\mathrm{Pl} 8$}

本帯は下部ペルム系の最上部を示す化石帯であり，Misellina claudiae を代表種として設定したもので ある。本帯はPseudofusulina ambigua 帯の上に整合に累重し, Misellina claudiae (DEPRAT) の出現 より Parafusulina kaerimizensis (OZAWA) の出現までの石灰岩層で層厚 $20 \mathrm{~m}$ である。本帯に属する 石灰岩層は各所で部分的に 発見されているが，“帰り水”地域では最もよく典型的に発達しており，鍵層 として追跡される。主要産出化石は次のとおりである。

Misellina claudiae, M. ovalis, M. otai, Nagatoella orientis, N. kobayashii, Toriyamaella sp., Pseudofusulina ambigua, P. kraffti magna, Maklaya akiyoshiensis (MS) Akagophyllum 
akagoensis.

本帯はテチス地域の Sakmarian 上部, 北米の Leonardian の下部に対比される。

15) Parafusulina kaerimizensis 帯, Pma $a_{1}$

本帯は中部ペルム系の最下部を示す化石帯で層厚 $25 \mathrm{~m}$ である。本帯の分布は秋吉台では“帰り水”ド リーネ地域, 剣山附近, 西の台では於福台 $409.5 \mathrm{~m}$ の東斜面, 河原の東, 入見の東などに分布する。標式 的に本帯を観察できるのは“㴆り水”附近である。下部の Misellina claudiae 帯との関係は, 湊・加 藤・長谷川 (1964) によれば Pseudofusulina zone（筆者らの Pseudofusulina ambigua zone + Misellina claudiae zone) の化石群集ならびに岩相と, Parafusulina kaerimizensis zone の化石群集・岩 相とに急激な変化があり，またPseudofusulina zone の上部はやや泥質になり，化石の破片を含む石灰 岩の角礫質のものを夾むことがあるので，両帯の間に不整合の存在を推定している。筆者らの調査でも Misellina claudiae zone の石灰岩はやや泥質で matrix は micritic の部分が多く, 上部では磁質な部分 があることがわかつた。それに対して Parafusulina kaerimizensis zone の石灰岩では matrix は sparry calcite の部分が多いので古環境に変化があつたことは観察される。しかし，化石帯が部分的に欠除した り両帯の石灰岩層の裮曲に差のあらわれるほど大きい不整合関係は, “帰り水”地域の地表調査ならびに ボーリングによる岩芯調査では観察されない。しかし小さな不整合の存在は充分考えられるので, 今後导 つと広い地域について検討してみる必要があると考えられる。本带の主要化石は次のとおりである。

Parafusulina kaerimizensis, P. edoensis, P. gigantea, Pseudodoliolina ozawai, 本帯はテチス地域の Artinskian, 北米の Leonardian 上部に対比される。

16) Afghanella schencki 帯, Pma

本帯はこれまで Parafusulina kaerimizensis 帯の石灰岩とされていたもののうち, Afghanella schencki の出現から Neoschwagerina craticulifera の出現するまでの間の石灰岩層を分帯したものであ る。本帯は Parafusulina kaerimizensis 帯の上に整合に累重し, 層厚は平均 $15 \mathrm{~m}$ である。本帯の主要 産出化石は次のとおりである。

Afghanella schencki, A. ozawai, Parafusulina kaerimizensis, Verbeekina sp., Pseudofusulina sp.

本帯の分布は秋吉台，東の台，西の台ともに点々と知られているが，“帰り水”地域で最も典型的に発達し ている。本帯はテチス地域の Artinskian 最上部, 北米の Leonardian 最上部に対比される。

17) Neoschwagerina craticulifera 帯, $\operatorname{Pm} \beta$

本帯は Afghanella schencki 帯の上位に整合に重なる化石帯で層厚は平均 $25 \mathrm{~m}$ である。本帯の分布は 秋吉台では“帰り水”ドリーネ附近, 西の台では於福台の $409.5 \mathrm{~m}$ 高地の東側傾斜面一带, 入見の東側, 奥河原の東側などにみられるが“帰り水”地域で最もよく観察される。本帯の主要産出化石は次のとおり である。

Neoshwagerina craticulifera, N. simplex, N. haydeni, Parafusulina kaerimizensis, Pseudofusulina pseudolepida, P. ozawai.

本帯はテチス地域の Guadalupian 下部, 北米の Wordian に対比される。

\section{8) Verbeekina verbeeki 帯, $\operatorname{Pm} \gamma$}

本帯は Neoschwagerina craticulifera 帯の上位に 累重するもので層厚平均 $20 \mathrm{~m}$ である。本帯の分布 は秋吉台の“帰り水”，西の台では萩原旧採石場附近，江原西部に部分的にみられる。この化石帯は世界的 红広く分布しており，国際対比の上で重要な化石帯である。主要産出化石は次のとおりである。

Verbeekina verbeeki, Colania douvillei, Colania megaspherica, Chusenella sp., Codonofusiella sp.

本帯はテチス地域の Guadalupian の中部, 北米の Capitanion 最下部に対比される。 


\section{9) Colania douvillei 帯, Pm8}

本帯は中部ペルム系最上部を示す化石帯で Verbeekina verbeeki 帯の上位に整合に累重し，層厚は平均 $40 \mathrm{~m}$ である。“帰り水”ドリーネ附近, 芹田の南, 江原の西側, 萩原旧採石場附近, 重安駅の東側など点 々と部分的に分布している。萩原旧採石場附近で観察される本帯はもつとも典型的なものである。主要産 出化石は次のとおりである。

Colania douvillei, C. megaspherica, Neoschwagerina haydeni, Chusenella sp., Pseudofusulina sp.

本帯はテチス地域の Gnadalupian 中上部, 北米の Capitanian 下部に対比される。

\section{0) Lepidolina multiseptata shiraiwensis 帯, Pua}

秋吉石灰岩層群の最上部を占める上部ペルム系下部を示す化石帯で Colania douvillei 帯上に不整合に 重なつている。層厚は $25 \mathrm{~m}$ 。本帯に属する石灰岩層は大部分が灰〜暗灰色の角砂状石灰岩であるが，上部 では部分的に黒色泥岩に漸移しているところもある。分布は西の台に限られており秋吉台ではみられな い。萩原の旧採石場附近, 入見附近, 重安駅の東側などに部分的に分布する。主要産出化石は次のとおり.

Lepidolina multiseptata shiraiwensis, L. multiseptata pinguis, Sumatrina longissima, Verbeekina sp., Codonofusiella sp.

本帯はテチス地域の Guadalupian 上部，北米の Capitanian 上部に対比される。

\section{2.“帰り水”地域における逆転の事実}

秋吉石灰岩層群の逆転構造を解明するには小沢（1923）が述べているように，逆転構造が最も典型的で ある地域における研究が必要である。秋吉石灰岩層群分布地全域のうちこのような地域が数力所ある。す なわち, 帰り水”ドリーネ地域, 江原ウバーレ地域, 於福台 $409.5 \mathrm{~m}$ 高地一带, 岩永台・姥ケ穴地域の 4 力所である。この 4 つの典型的地域の中でも小沢も述べたよらに“帰り水”ドリーネ地域は最もよく逆 転層を観察できる。そのためこの地域において逆転構造が認められるか否かは秋吉石灰岩層群全体の基本 的構造を解明する上に重要な鍵となつていた。このような地域であるため，これまで秋吉石灰岩層群の地 質構造，あるいは西南日本の造山運動史とその形態を論じてきた多くの研究者は“帰り水”ドリーネ地域 の構造に多くの興味と関心を示してきた。

しかしながら，前述のとおり，1958 年以来“帰り水”地域の広域逆転を否定して秋吉石灰岩層群の地質 構造を論ずる研究者と, 広域逆転を認め西南日本の造構史を考察する研究者の間に多くの論議を生じてき た。このため筆者らは “帰り水”地域の地質構造を正確に把握し, 西南日本の構造発達史の解明の一助と するため，1960 年以来次のような一連の研究計画を立て実行してきた。

\section{1）“帰り水”地域の地表面における化石帯の詳細な分布図の作製}

地質構造をより正確に把握するために精度の高い地表面調査を行ない，またその際観察される諸地質現 象の資料も考慮して秋吉石灰岩層群全体の地質構造を考察する。この場合，問題になるのは，古生層分布 地域に掠いて地表面調查によつて地表面下 200 ～ $300 \mathrm{~m}$ までの地質構造を 推定する場合，ぞれほどの精度 を必要とするかである。この調査精度の検討に当つて第三紀層中の石炭を採掘する場合に 各鉱山で行なわ れている地質調查の精度と金属鉱床，とくに古生層中に賦存している 金属鉱床の鉱体を地質調查から推定 する場合行なわれる調查の精度を基準に 検討した。その結果，最終的なまとめの精度が $1 / 1000$ 地質図にな る程度の精度が必要であるといら結論に達した。このため地表調查を次のような手順で行なつた。

i ）地形図はトランシット測量による実測図を作製する。

ii）地形測量の際，地質調查の基本測線として“㴆り水”ドリーネ底の中央部を基点に東西，南北に測 線を設け, $100 \mathrm{~m}$ おきにセメント杭を, $10 \mathrm{~m}$ おきに木杭を打ち, 標本採集地点を正確に地形実測図上に プロットし，標本の空間的位置づけを正確にする。 

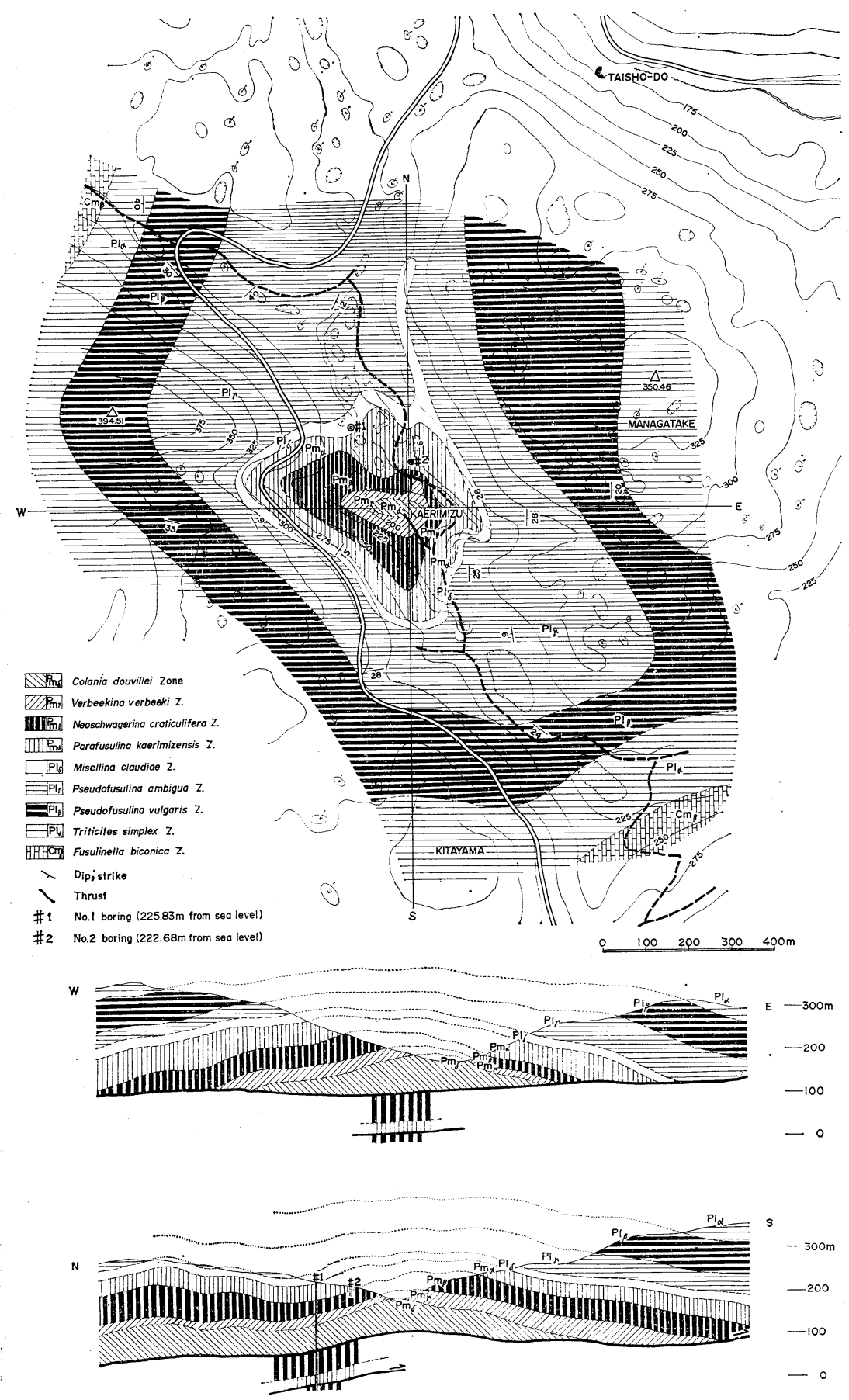

Fig. 3 Geologic map of kaerimizu area 
iii）標本を採集する場合には水平ならびに南北の方位を記して採集する。これは化石の地層中に扔兴る 配列状態から地層の走向傾斜を推定するためである。(標本採集にあたつての現地調查図は $1 / 100 \sim 1 / 500$ で 行なつた)

iv）以上 $3 つ の$ 作業を中心調査を進めてゆくうち，石灰岩層中にラミナの面が特徵的に発達している 部分が存在する事実が判明した。このため石灰岩のラミナの走向，傾斜を測定し，地形図上に記入してゆ く作業を併用した。

v) また各石灰岩層中に泥質石灰岩 (micritic limestone), 砂質石灰岩 (sparry calcite matrix limestone）および砅質石灰岩（conglomeratic limestone）の部分が存在し，岩質の変化からも堆積面を知るこ とができることが明らかになった。このため鍵層になるような部分を選び，これを追跡することによつて 最も正確に構造を決定できると考えた。

以上の結果, “帰り水”地域に扔いては化石群の構成, 岩相, 分布域なぞから Misellina claudiae 帯が 最もよい鍵層であることが判明し，この化石带の追跡作業を加えて行なつた。Misellina claudiae 带を鍵 層に選んだ理由は a) 上，下の化石帯は砂質石灰岩層を主としているのに対し，M. claudiae 帯では泥質 石灰岩層の部分が多く，単層面が観察できること。b）化石群の構成が極めて特徽的であり，また Misellina claudiae (DEPRAT) は種として形態が特徴的で野外でも他のフズリナ化石より容易に識別される 点，c）さらに Misellina claudiae は密集層を形成し，その厚さが $2 \mathrm{~m}$ 前後しかないこと，d）分布域が かなり広く，下部ペルム系と中部ペルム系の境界になる化石帯であること，などからである。

以上の作業手順で研究を進め, 筆者らは第 3 図のような “帰り水”地域の地形, 地質図ならびに地質断 面図を作製した。(この地質断面図には後で述べる第 1 号ボーリングから得られた結果も加えられている。)

第1にこの図で明らかなように“帰り水”ドリーネ地域には下部ペルム系最下部の化石帯から中部ペル ム系最上部の化石帯までがほぼ“帰り水”ドリーネを中心にして，これを取り巻くよら分布している。

“帰り水”地域で分帯識別された化石帯は上部より第 4 表のように 10 化石帯である (Parafusulina kaerimizensis 帯 $\alpha_{1}$ の上に重なる Afghanella schencki 帯 $\alpha_{2}$ は第 3 図の地質図では Parafusulina kaerimizensis 帯に含めてある。またPseudoschragerina (P.) muongthensis zone は“帰り水”地域では分 帯できなかつた)。各化石帯の構成種群は前述したので省略する。

第 4 表“帰り水”地域の化石带

\begin{tabular}{c|l|l}
\hline \hline 中 & Colania douvillei Zone & $\operatorname{Pm} \delta$ \\
部 & Verbeekina verbeeki Zone & $\operatorname{Pm} \gamma$ \\
ヘ & Neoschwagerina craticulifera Zone & $\operatorname{Pm} \beta$ \\
$\Delta$ & Afghanella schencki Zone & $\operatorname{Pm} \alpha_{2}$ \\
紀 & Parafusulina kaerimizensis Zone & $\operatorname{Pm} \alpha_{1}$ \\
\hline 下 & Misellina claudiae Zone & $\mathrm{Pl} \delta$ \\
部 & Pseudofusulina ambigua Zone & $\mathrm{Pl} \gamma$ \\
ル & Pseudofusulian vulgaris Zone & $\mathrm{Pl} \beta$ \\
紀 & Tritictessimplex Zone & $\mathrm{Pl} \alpha 1$ \\
\hline 石炭紀 & Fusulinella biconica Zone & $\mathrm{Cm} \beta$
\end{tabular}

第 2 亿は“帰り水”地域の走向は $\mathrm{NE} 20^{\circ} \sim \mathrm{NW} 20^{\circ}$ で, 傾斜法平均 E $15^{\circ}$ である。しかし，ドリー ネの最外縁部ではそれぞれ“㴆り水”を中心に外側に向つて傾斜しており，ややドーム状構造を形成して いる。

第 3 には踺層としてその分布を正確に追跡した Misellina claudiae 带の Misellina claudiae(DEPRAT) 
化石群集の密集した化石層（厚さ約 $2 \mathrm{~m}$ ）は“帰り水”ドリーネの東側ではほぼ等高線に沿つて追跡され， “帰り水”ドリーネの西側ではやや等高線を切って西側に上るように分布している。また“帰り水”の谷 に沿つた部分では南北に長く追跡された。以上のように Misellina claudiae 化石群の密集層は完全に“帰 り水”ドリーネの中腹をぬつて一周追跡された。このようにして追跡された化石層と等高線との関係から 図上で計算された一般走向・傾斜と露頭でクリノコンパスによつて測定された 走向・傾斜の值はほぼ一致 した。以上の地表調查結果から“帰り水”ドリーネ地域では明らかに広域な逆転構造の存在が結論される。

2） ボーリングによる地下層序の検討

“帰り水”地域の詳細な地表面の調査・研究とほぼ平行して準備を進めてきたボーリングによる地下化 石層序学的検討作業を 1970 年より実行に移した。このボーリング計画は 1963 年より特別天然記念物秋吉 台の構造解釈のために 秋吉台科学博物館の 機関研究計画として 進められた。毎年約 40 万円の費用を投じ てボーリング機械一式を部分的に購入してゆき，筆者ら自身で機械を組み立て掘削作業を行ない，岩芯を 啋集する計画で進められた。

以上のような計画のもとで，ボーリング 第 1 号井は“帰り水”ドリーネの北側約 $200 \mathrm{~m}$ の Misellina claudiae 帯の上部, 北緯 $34^{\circ} 15^{\prime} 97^{\prime \prime}$ ，東経 $131^{\circ} 18^{\prime} 91^{\prime \prime}$ ，海抜 $225.83 \mathrm{~m}$ 地点汇設置された。このボーリン グはできるだけ岩芯の採集率をよくするためダブル・コア・チューブを使用し，最初は $75 \mathrm{~mm}$ 径のビッ トで掘削を開始, 深度 $19 \mathrm{~m}$ でケーシングをしてビットを $55 \mathrm{~mm}$ 径にして掘り進しだ。したがつて $19 \mathrm{~m}$ より深部で採取された岩芯の直径は約 $50 \mathrm{~mm}$ である。筆者ら自身が機械の操作をしたので，できるだけ 岩芯採集梁度が正確になるように時間をかけることができた。現地において岩芯にスケールをあて $10 \mathrm{~cm}$ おきに深度を記入するとともにルーペで観察し，含化石層の傾斜，岩相などを記録していつた（現場の作 業は主に太田・杉村・配川で受け持ち，鳥山は全般的指導を行なつた)。岩芯は掘進日ごとに研究室に持 ち帰り岩芯収納箱に整理された。できるだけ正確を期するため化石群集の解析, 岩相の観察等を掘削作業 と平行して行なつたので掘進は遅れたが，1971 年 2 月 5 日に深度 $213 \mathrm{~m}$ に達した。

深度 $213 \mathrm{~m}$ までのうち深度 $162 \mathrm{~m}$ で逆転部（化石帯の出現順序が 逆位の部分）を過ぎ，再び下位の化 石帯があらわれることが判明した。しかし深度 $213 \mathrm{~m}$ までは同一化石帯で次の化石帯に 達しなかつたた め, その下がはたして正位なのか逆位なのかが不明であつた。この下の化石帯が何であるが構造決定上 極めて重要なので, ボーリング機械の能力 $(200 \mathrm{~m})$ を過ぎていたが 補助機械をつけ, さらに約 $50 \mathrm{~m}$ 掘 進することにした。1972 年 2 月 25 日深度 $250 \mathrm{~m}$ に達し海面下の位置 $(-24 \mathrm{~m})$ まで掘削が進み, 下の化 石帯を確かめ得たので第 1 号井の掘削作業を完了させた。

採集岩芯は全部中央で縦に切半し片面を研磨して岩相を検討し, 永久保存用とした。また残り半分は薄 片, 分析, その他の研究用資料とし, 研究者に使用できるよらに計画した。筆者らはこの研究資料用の岩 芯より薄片 120 枚を作製し, 微古生物学的および生層序学的研究を行なつた。その結果第 1 号井の柱状図 を作成したものが第 4 図である。すなわち地表面より次のような順で化石帯が認められた。

\section{化 石 帯}

Misellina claudiae 帯

Parafusulina kaerimizensis 帯

Afghanella schencki 帯

Neoschwagerina craticulifera 帯

Verbeekina verbeeki 帯

Colania douvillei 帯

- thrust-

Neoschwagerina craticulifera 帯

Afghanella schencki 帯

- thrust-

Neoschwagerina craticulifera 帯

深 度
$0 \sim 16 \mathrm{~m}$
$16 \mathrm{~m} \sim 31 \mathrm{~m}$
$31 \mathrm{~m} \sim 41 \mathrm{~m}$
$41 \mathrm{~m} \sim 73 \mathrm{~m}$
$73 \mathrm{~m} \sim 97 \mathrm{~m}$
$97 \mathrm{~m} \sim 162 \mathrm{~m}$

$162 \mathrm{~m} \sim 217 \mathrm{~m}$

$217 \mathrm{~m} \sim 242 \mathrm{~m}$

$242 \mathrm{~m} \sim 250.56 \mathrm{~m}$

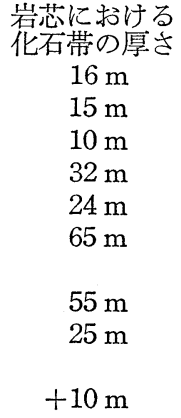




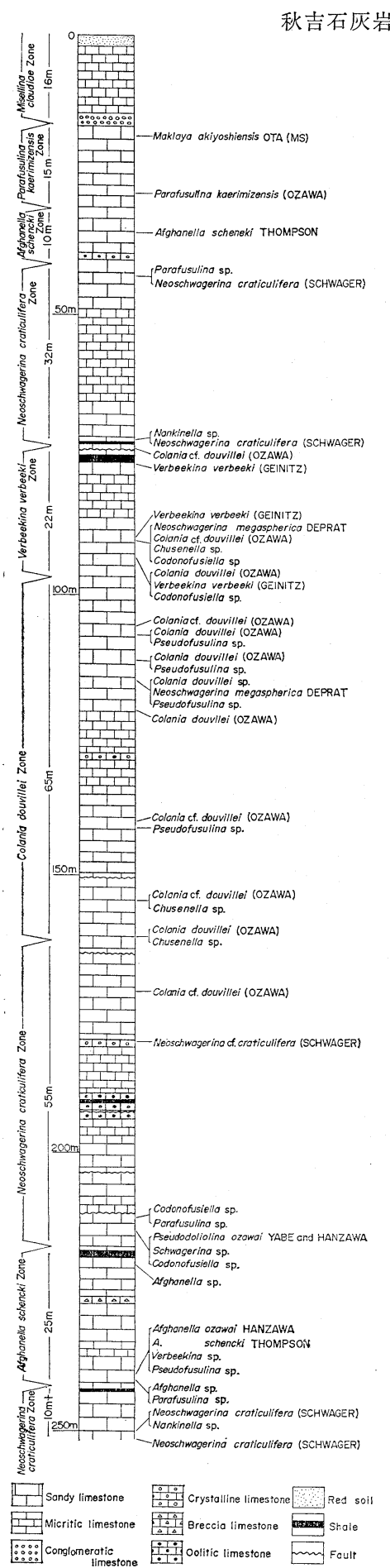

第 4 図帰り水ボーリング第 1 号柱状図

(Fig. 4 Columnar section of Kaerimizu boring No. 1)
上記のことから明らかなように，地表より深度 $162 \mathrm{~m}$ までは化石帯は連続的に完全に逆の順序であらわれ，そ の間に化石帯の欠除はみられない。従つて“帰り水”に おける秋吉石灰岩層群の逆転は全く疑らことのできない 事実であることが判明した。第 1 号ボーリングが計画さ れたとき，筆者らは，秋吉台（東の台）では地表で確認 されていない上部ペルム系の Lepidolina murtiseptata shiraiwensis 帯の存在を期待した。しかし, 第 1 号井で はペルム系化石帯の最上部は Colania douvillei 帯で, その下は衝上断層で切られ, 層序的に下位の Neoschwagerina craticulifera 帯が出現することが明らかになつ た。次に柱状断面図で明らかなように逆転部では地層が ほとんど乱されていないのに対し, 深度 $162 \mathrm{~m}$ 以下の正 位の部分では地層は逆転部より強く擾乱をうけ小褶曲を 形成するとともに，衝上断層が頻繁にできている。この ことは褶曲断層構造の形態を考察する上で重要な資料で ある。

以上が“帰り水”学術第 1 号ボーリングによる地下層 序研究の経過と結果であり, 現在第 2 号ボーリングの掘 削にかかつている。現在のボーリングの全体計画では同 一層準より 3 本のボーリングを行ない，各化石帯の厚 さ，地層の傾斜，褶曲の状態などを正確に知ることを目 的にしている。しかし，将来は下部ペルム系および石炭 系の石灰岩層の層厚, 化石带, 構造, 形態を明らかにす るためにさらにボーリングを追加してゆきたいと望んで いる。

\section{3. 秋吉石灰岩層群の地質構造とその形成の時代}

前述のとおり 秋吉石灰岩層群中に識別される 20 の化 石带に基礎を扮いて，秋吉石灰岩層群の全分布地域にお いて精度 $1 / 5000$ で地質調查を行なつた。この結果と, 森 永・太田（1971）の秋芳町真木，住友セメント採石場で 行なつたボーリングによる地下地質調查ならびに“帰り 水” 学術第 1 号ボーリングの結果, さらに太田（1968） の秋吉石灰岩層群の生相, 岩相より解析した地質構造の 結果を加えて作製した秋吉地域の地質図，ならびに地質 断面図が第 5 図である。

この地質図・地質断面図および筆者らのこれまでの研 究結果を総合すると，秋吉石灰岩層群はほぼ現地に近い 場所で生物礁複合体の石灰岩塊として堆積したのち, NNW から SSE に働く側圧と，WからEに働く趈転力 とが併合された造構運動で石灰岩層は大きく $\mathrm{N} か ら \mathrm{~S} に$ 褶曲したと考穴られる。その結果秋吉石灰岩層の北半部 
演横卧袮曲を形成し，向斜軸部にできた衝上断層に沿い南半部の正位の石灰岩層上に衝上したとみなされ る。北半部の横卧褶曲の上翼部はその後の溶蝕作用で削り取られ，現在下翼の逆転部が露出している。こ の横臥褶曲の形成の時期については従来の知見と大差はないが次の点が指摘される。

1）萩原地域では逆転部石灰岩層の見掛け上の最下部は Lepidolina multiseptata shiraiwensis 帯に 属する石灰岩層である。この石灰岩層は見掛け上, さらに下位にある別府・雁飛層群に属する黒色泥岩層 潮移しており，この漸移部の黒色泥岩層中からも Lepidolina multiseptata shiraiwensis (OzAWA) が 発見されている。したがって，この部分では非石灰相の別府・鹰飛層群は秋吉石厕岩層群とともに逆転し ていることは明らかである。同様な関係は芹田地域においても観察される。別府・雁飛層群の最上部がど の時代にまで及ぶかは現在までの資料では明らかではない。しかし同層上部の粗粒砂岩層中に Lepidolina multiseptata shiraiwensis (OzAWA) の破砕片を多く含む部分があるので別府・雁飛層群には上部ペルム 系のかなり上部まで存在するものと推定される。

2) 秋吉石灰岩層群の周辺部に分布する古生界, すなわち別府・雁飛層群, 常森層群, 大田層群はいゔ れもこれまでの研究から秋吉石灰岩層群の同時異相とされている。別府・雁飛層群, 常森層群の分布地域 のさらに西側に非常にゆるやかな構造でモラッセ型堆積物である上部三畳系の 美爾層群が分布している。

この美爾層群と古生界との構造関係にはまだ多くの疑問点が残されているが，秋吉石灰岩層群の主要な裮 曲時期はこの美爾層群堆積前であることは疑いない。

以上の 2 点から秋吉石灰岩層群に見られる大きな横卧褶曲が形成された時期は, ペルム紀後期末一三畳 紀後期前であることは明らかである。筆者らのこれまでの研究では, 現在非石灰古生界とみなしている地 層中に岩相上三畳系に属するのではないかといら疑問がある地層が存在するので，今後の調查によっては 古生界とみなされている地層中に下部三畳系の地層が発見される可能性がある。1941 年小林貞一はこの大 きな横卧褶曲構造をともなら一連の地殻変動に対し, 小沢儀明の功績を記念して「秋吉造山運動」と命名 した。一時はこの大規模な横臥褶曲に疑問がもたれ秋吉造山運動の存在にも疑問がなげかけられたが，ボ ーリングによつて地下に逆転部の存在が実証されたので，秋吉造山運動の実在は疑らことのできないもの である。

\section{IV 結 論}

以上論述してきた結果をまとめると，次のように結論される。

1. 秋吉石灰岩層群は石炭紀前期よりペルム紀後期までの間に堆積したものであり, フズリナ化石群集 およびサンゴ化石群集より 20 の化石帯（第 3 表）に分帯される。

2. 秋吉石灰岩層群の逆転構造を典型的に示す地域として知られていた“帰り水”ドリーネ地域におい て逆転層の存在に疑問がもたれてきたので, これを解明するため深度 $250 \mathrm{~m}$ に達するボーリングを行なつ た。

3. ボーリングの岩芯から得られた地下層序で Misellina claudiae 帯より Colania douvillei 帯まで の化石帯が完全に逆転していることが確認された。また，この逆転部は衝上断層で正位の石灰岩層と接し ていることが判明した。これらの結果と精度を高くした地表調查の結果から，秋吉石灰岩層群全体にわた る逆転構造の存在は動かすことのできない事実として実証された。

4. 秋吉石灰岩層群における 20 の化石带の分布状態, 周辺の非石灰相の古生界の層序, およびボーリン グによる地下層序を考察した結果, 次のように結論される。すなわち, 秋吉石灰岩層群はペルム紀後一三 盢紀後期前の間に相対的に北から南に㗢く大きな地款変動を受け, 大規模横臥褶曲をともなら構造を形成 した。この造構造運動は秋吉造山運動であり，西南日本における古生代末より中生代初頭にかけての最す 規模の大きな激しい造山運動である。 


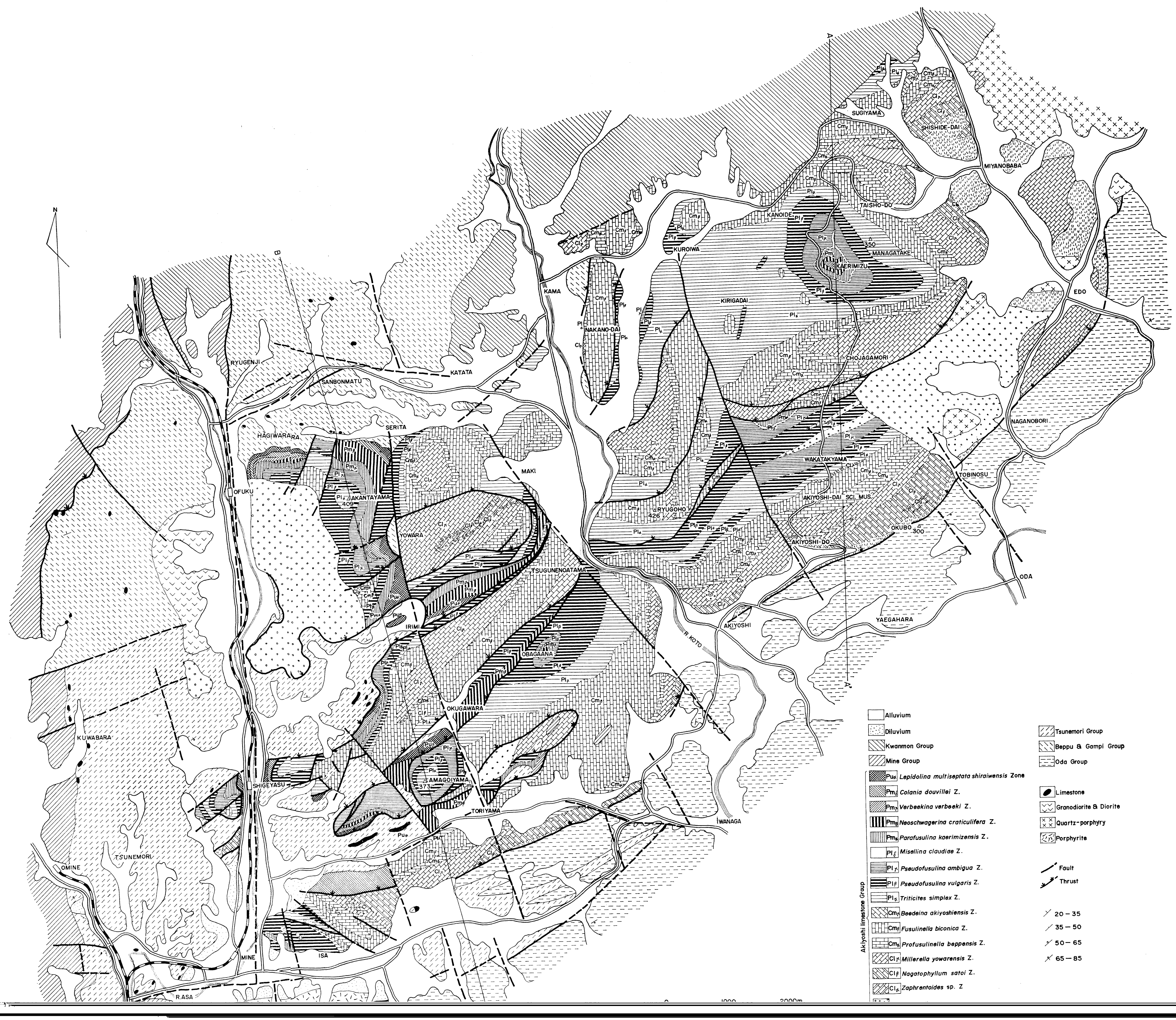




\section{引周文献 参考文献*}

Endo, R. (1961) : Stratigraphical and paleontological studies of the Later Paleozoic calcareous algae in Japan, XVII : Fossil algae from the Akiyoshi limeston Group. Sci. Rep. Saitama Univ. Ser. B, pp. 119-142, pls. 1-7.

衛藤蒸二 (1967) : 岩相による秋吉石灰岩層群下部層の解析. 秋吉台科学博物館報告, No. 4, pp. 142 , pls. $1-5$.

藤井厚志・三上貴彦 (1970)：常森層一之の秋吉石灰岩との関倸一。地質学雑誌，Vol. 76, No. 11, pp. 545-557.

藤井厚志 (1971)：砂岩重鉱物解析の一方法, 上部古生界常森・大田両層の砂岩を例として。地質学雑 誌, Vol. 77, No. 10, pp. 653-666.

藤井厚志 (1972)：秋吉地域の山口層群・大田層. 地質学䧴誌，Vol. 78, No. 6, pp. 309-321.

HANZAWA, S. (1941) : The stratigraphical relation between the Carboniferous and Permian Formation in the Manchuria, Korea ane Japan Proper. Japan. Jour. Geol. Geogr., Vol. 17, No. 3, pp. 97-108.

HANZAWA, S. (1944) : Stratigraphical distribution of Fusulinid foraminifera found in South Manchuria and Japan. Jour. Geol. Geogr., Vol. 19, Nos. 1-4, pp. 1-10.

長谷 晃(1951)：山口県の三畳系. 地質調查所報告特別号, pp. 73-89.

-(1958)：西中国・北九州の後期中世界の層序と構造. 広島大学地学研究報告, No. 6, pp. I-55. 長谷川美行 (1958)：秋吉台の地質構造汇関する一考察 (予報). 地球科学, No. 39, pp. 15-18.

HASEGAWA, Y. (1963) : New found of fossils in the reddish tuffaceaus shale in the Akiyoshi province. Earth Science, No. 64, pp. 32-37.

HASEgaWA, Y. (1967) : Profusulinella daiyamensis from the Profusulinella zone of the Akiyoshi limestone Group. Sci. Rep. Niigata Univ. Ser. E, No. 1, pp. 9-15.

速水 格(1973)：化石帯の進化学的解釈. 地質学雑誌, Vol. 79, No. 3. pp. 219-235.

市川浩一郎・藤田至則・島津光夫 (1970)：日本列島地質構造発達史, $232 \mathrm{pp}$. 築地書館, 東京.

IsHII, K. (1958) : On the phylogeny, morphology and distribution of Fusulina, Beedeina and allid fusulind genera. Jour. Inst. Polytehnica Osaka City Univ. Ser. G, Vol. 4, pp. 64-99.

IsHII, K. and NoGAMI, Y. (1964) : Contributions to the geology and paleontology of Cambodia Pt. 1. Permian Fusulinids. Jour. Geosci. Osaka City Univ. Vol. 8, Art. 2, pp. 9-37, pls. $1-8$.

勘米良象齢 (1953)：球磨層一特に日本の二畳系上部統に関して一．地質学雑誌，Vol. 59, No. 697, pp. $449-468$.

KANMERA, K. (1955) : Fusulinids from the Upper Permian Kuma Formation, Southen Kyushu, Japan-with special reference to the Fusulinid Zone in the Upper Permian of Japan. Mem. Fac. Sci. Kyushu Univ. Ser. D, Vol. 4, No. 1, pp. 1-38, pls. 1-6.

KANMERA, K. (1955) : Fusulinids from the Yayamadake Limestone of the Hikawa Valley, Kumamoto Prefecture, Kyushu, Japan. Pt. 2. Fusulinids of the Upper Carboniferous. Japan. Jour. Geol. Geogr.. Vol. 27, Nos. 3-4, pp. 177-192, pls. 11-12.

Kanmera, K. and Toriyama, R. (1968) : Fusulinacean Fossils from Thailand Pt. 3. Maklaya, New generic designation for Neoschwagerinids of the Group of Cancellina pamirica LEVEN. Geol. Palaeont. Southast Asia Vol. 5. pp. 31-46, pls. 4-5.

河野通弘 (1950)：秋吉台石灰岩について. 山口大学理学会誌, Vol. 1, pp. 49-54. pl. 8.

河野通弘 (1961)：秋吉台弥山附近の地質一特に紡銗虫化石帯について一. 秋吉台観音洞遺跡学術調查 報告, pp. 49-54.

KAwANo, M. (1967) : On the limestone in the neighbourhood of Managatake of the Akiyoshi Plateau. Bull. Akiyoshidai Sci. Mus. No. 4, pp. 1-6, pls. 1-2.

小林貞一(1939)：西南日本の地質構造. 地学雑誌, Vol. 51, No. 604, pp. 248-260.

—(1940)：長阴筑前の地質について. 地質学雑誌，Vol. 5, No. 616 .

* 本論文に引用したものの他, 秋吉石灰岩層群, その周辺の非石灰相の諸層群の層序・構造, 古生物に 関する文献，秋吉台を含も西南日本の地体構造に関する文献もまと掲げた。 
Kobayashi, T. (1941) : Sakawa Orogenic Cycle and its bearing on the prigin of the Japanese Islands. Jour. Fac. Sci. Imp. Univ. Toko. Ser. 20, Vol. 5, Pt. 7, pp. 219-578, pls. 1-4. 小林貞一(1948)：日本群島地質構造論, 上, 中巻.

小林貞一(1950)：日本地方地質誌，総論. $353 \mathrm{pp}$. 朝倉書店, 東京.

小林貞一(1951)：日本地方地質誌，中国地方. $241 \mathrm{pp}$. 朝合書店, 東京.

小林貞一(1959)：古期中生代の秋吉褶曲山脈. 地学雑誌, Vol. 68, No. 3, pp. 1-9.

小林貞一(1970)：中北满とその近隣の満蒙層群と秋吉造山運動について。地学雑誌，Vol. 79, No. 4, pp. 4, pp. 1-29.

Matsumoto, T. (1949): The Late Mesozoic Geological History in the Nagato Province, Southwest Japan. Japan. Jour. Geol. Geogr., Vol. 21, Nos. 1-4, pp. 235-243.

Minato, M. and Kato, M. (1957) : On the Carboniferous Coral Zone in the Akiyoshi Plateau, Southwest Japan. Proc. Japan Acad. Vol. 33, No. 9, pp. 541-546.

Minato, M., Kato, M. and HASEgawA, Y. (1964) : A note on the boundary between Pseudofusulina and Parafusulina Zone in Japan. Proc. Japan Acad. Vol. 40, No. 10, pp. 827-831.

Minato, M., Gorai, M. and Hunahashi, M. (editors) (1965) : The Geologic development of the Japanese Island. 442 pp. Tsukiji shokan Co., Ltd. Tokyo.

MoRINAGA, Y and OTA, M. (1971) : Subsurface geology of the Akiyoshi limestone Group in the Maki and Kyoei Area, Shuho Town, Southwest Japan. Bull. Akiyoshi.dai Sci. Mus. No. 7, pp. 25-56, pl. 8 .

村田正文 (1958)：秋吉台の質地構造 (その一)有孔虫. No. 9, pp. 10-19.

村田正文 (1961)：秋吉台の地質構造. 東北大学理学部地質古生物学教室研究邦文報告, No. 53, pp. $1-46$.

NishidA, T. (1968): A new species of Conocarium from the Carboniferous of Akiyoshi. Trans. Proc. Palaeont. Soc. Japan, N. S. No. 69, pp. 207-210, pl. 23.

NishidA, T. (1968) : On some Gastropods from Millerella zone of the Akiyoshi limestone Group. Trans. Proc. Palaeont. Soc. Japan, N. S. No. 70, pp. 233-237.

NishidA, T. (1971) : Carboniferous Ammonoids from Akiyoshi. Bull. Akiyoshi-dai. Sci. Mus. No. 7, pp. 1-24, pls. $1-7$.

沖村雄二(1963) : 秋吉石灰岩層群 Profusulinella beppensis 带以下の有孔虫化石带. 広島大学地学研 究報告, No. 12, pp. 305-318, pl. 39 .

沖村雄二 (1966) : 中国地方下部石灰系の微化石層序学的研究. 広島大学地学研究報告, No. 15, pp. $1-46$, pl. 1.

太田正道 (1968)：地向斜生物礁複合体としての秋吉石灰岩層群. 秋吉台科学博物館報告, No. 5 , pp. 1-44, pls. 1-31.

OTA, M. (1971) : Faunas and correlation of the "Uzura" Quarry limestone of Akiyoshi, Southwest Japan; Pt. 2, Fusulinian fauna. Bull. Akiyoshi-dai Sci. Mus. No. 7, pp. 65-74, pls. 12-13.

太田正道 (1971)：秋吉石灰岩層群と逆転構造. 地学研究, Vol. 22，Nos. 11-12，pp. 432-438.

Ota, N., Sugimura, A. and Ota, M. (1969) : Reef deposits in the Millerella zone of the Akiyoshi limestone Group. Trans. Proc. Palaeont. Soc. Japan, Special papers. No. 14, pp. 1-12, pls. 1-3.

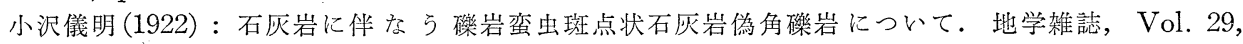
No. 351 .

小沢儀明 (1923)：秋吉石灰岩を含む所謂秩父古生層の層位学的研究. 地質学雑誌, Vol. 30, No. 357, pp. 227-243.

OzAwA, Y. (1925) : Palaeontological and Stratigraphical studies on the Permo-Carboniferous limestone of Nagato, Pt. 2, Palaeontology, Jour. Coll. Sci. Imp. Univ. Tokyos. Vol. 45, Art. 6 , pp. $1-90$, pls. $1-4$.

Sakagami, S. (1964) : Bryozoa of Akiyoshi, Pt. 1, Permian bryozoa from the Shigeyasu Quwrry. Bull. Akiyosh-dai Sci. Mus. No. 3, pp. 1-24, pls. 1-8.

Sakagami, S. (1964) : Bryozoa of Akiyoshi, Pt. 2. Lower Carboniferous bryoza from the 
Uzura Quarry. Trans. Proc. Palaeont. Soc. Japan. N. S. No. 56, pp. 295-308, pls. 44-45. ShikAMA, T. and NishidA, T. (1968) : One some species of Carboniferous Pleurotomariacans from Akiyoshi. Trans. Proc. Palaeont. Soc. Japan. N. S. No. 69, pp. 211-217, pls. $24-25$.

SugimurA, A. and OTA, M. (1971) : A bryozoan reef found near the Lowest part of the Akiyoshi limestone Group.-Bryozoa of Akiyoshi, Pt. 3-. Bull. Akiyoshi-dai Sci. Mus. No. 7, pp. 57-63, pls. 9-11.

SugimurA, A. (1972) : Three new species of the Genus Hayasakapora from Akiyoshi limestone Group.-Bryozoa of Akiyoshi, Pt. 4-. Bull. Akiyoshi-dai Sci. Mus. pp. 1-6, pls. 1-2. 柇山敏郎 (1939)：山口県美爾郡秋吉地方の古生層の 2 ・ 3 の事事実について. 地質学雑誌, Vol. 46, No. 544, pp. 13-22.

Takai, F., Matsumoto, T. and Toriyama, R. (editors) (1963) : Geology of Japan. 279 pp. Univ. of Tokyo Press, Tokyo.

Toriyama, R. (1954) : Geology of Akiyoshi, Pt. 1. Stratigraphy of the Akiyoshi limestone Group. Mem. Fac. Sci. Kyushu Univ., Ser. D. Vol. 4, No. 1, pp. 39-97.

ToriyamA, R. (1954) : Geology of Akiyoshi, Pt. 2. Stratigraphy of the Noncalcareous Groups developed around the Akiyoshi limestone Group. Mem. Fac. Sci. Kyusnu Univ., Ser. D, Vol. 5, No. 1, pp. 1-46.

鳥山隆三 (1957)：秋吉台の地質. 山口県教育委員会, pp. 1-36.

TORIYAMA; R. (1958) : Geology of Akiyoshi, Pt. 3. Fusulinids of Akiyoshi. Mem. Fac. Sci. Kyushu Univ., Ser. D, Vol. 7, pp. 1-264, pls. 1-48.

Toriyama, R. (1967) : The Fusulinacean Zones of Japan. Mem. Fac. Sci. Kyushu Univ. Ser. D, Vol. 18, No. 1, pp. 35-260.

矢部長克 (1958)：秋吉台地質構造につ々ての若干の問題. 有孔虫, No. 9, pp. 1-9.

YAmagiwA, N. and OTA, M. (1963) : Faunas and Correlation of "Uzura" Quarry, Akiyoshi, Southwest Japan. Pt. 1, Corals. Bull. Akiyoshi.dai Sci. Mus. No. 2, pp. 87-93, pls. 1-2.

YANAGIDA, J. (1962) : Carboniferous Brachiopods from Akiyoshi, Southwes Japan, Pt. 1. Mem. Fac. Sci. Kyushu Univ., Ser. D. Vol. 12, No. 1, pp. 87-127, pls. 14-21.

YANAGIDA, J. (1965) : Carboniferous Brachiopods from Akiyoshi, Southwest Japan, Pt. 2. Mem. Fac. Sci. Kyushu Univ., Ser. D, Vol. 16, No. 16, pp. 113-142, pls. 25-28.

YANAGIDA, J. (1968) : Carboniferous Brachiopods from Akiyoshi, Southwest Japan, Pt. 3. Delepinea from a pyroclastic rock near lowest part of the Akiyoshi limestone Group. Trans. Proc. Paraeont. Soc. Japan, N. S. No. 72, pp. 327-339, pls. 33-34.

柳田寿一・太田正道・杉村昭弘・配川武彦 (1971) : 秋吉台東部の地質. 九州大学理学部研究報告, 地 質学, Vol. 11, No. 1, pp. 105-114, pls. 7-10. 